\title{
PERAN BRAND AWARENESS DALAM MEMEDIASI PENGARUH CELEBRITY ENDORSER TERHADAP PURCHASE INTENTION
}

\author{
Ida Bagus Putu Asdhi Setiawan' \\ Ni Made Asti Aksari² \\ ${ }^{1,2}$ Fakultas Ekonomi dan Bisnis Universitas Udayana (Unud), Bali, Indonesia \\ email: ibasdhisetiawan@gmail.com
}

\begin{abstract}
ABSTRAK
Tujuan penelitian ini adalah untuk mengetahui peran brand awareness dalam memediasi pengaruh celebrity endorser terhadap purchase intention pada produk sepatu Adidas Yeezy. Penelitian ini dilakukan di Provinsi Bali dengan menggunakan sampel sebanyak 60 responden melalui metode non-probablity sampling dengan teknik purposive sampling. Teknik analisis data yang digunakan adalah analisis jalur (path analysis) dan uji Sobel. Hasil penelitian menunjukkan bahwa celebrity endorser berpengaruh positif dan signifikan terhadap brand awareness dan purchase intention; brand awareness berpengaruh positif dan signifikan terhadap purchase intention; dan brand awareness secara signifikan mampu memediasi pengaruh celebrity endorser terhadap purchase intention. Hasil penelitian ini mengindikasikan bahwa brand awareness dan celebrity endorser yang baik akan mampu mempengaruhi purchase intention pada produk sepatu Adidas Yeezy.
\end{abstract}

Kata kunci: celebrity endorser, brand awareness, purchase intention

\begin{abstract}
The purpose of this study was to determine the role of brand awareness in mediating the effect of celebrity endorser towards purchase intention on Adidas Yeezy shoe products. This research was conducted in the Province of Bali with a sample of 60 respondents using nonprobability sampling method with purposive sampling technique. Data was analysed using path analysis and Sobel test. Study result showed that celebrity endorser have a positive and significant effect on brand awareness and purchase intention; brand awareness have a positive and significant effect on purchase intention; and brand awareness can significantly mediate the influence of celebrity endorser on purchase intention. The result of this study indicates that good brand awareness and celebrity endorser can influence the purchase intention of Adidas Yeezy shoe products.

Keywords: celebrity endorser, brand awareness, purchase intention
\end{abstract}




\section{PENDAHULUAN}

Dewasa ini, perkembangan fashion sangat cepat terjadi di masyarakat. Banyak masyarakat yang menjadi konsumen fashion yang diciptakan oleh brandbrand terkemuka di dunia. Tingginya permintaan masyarakat akan produk-produk fashion berdampak pada banyaknya perusahaan di bidang fashion bermunculan. Ini mengakibatkan persaingan bisnis antar perusahaan fashion semakin ketat. Salah satu perusahaan yang terkenal di bidang fashion adalah Adidas. Adidas memproduksi berbagai jenis produk pakaian olahraga salah satunya adalah sepatu. Sepatu Adidas terdiri dari berbagai tipe seperti: Ultraboost, Alphaboost, NMD, Yeezy, Alphabounce, dan Superstar. Sepatu Adidas yang memiliki purchase intention yang tinggi diantara tipe sepatu Adidas yang lain adalah Adidas Yeezy.

Purchase intention (niat beli) adalah sesuatu yang timbul pada benak konsumen setelah menerima rangsangan dari produk yang dilihatnya, lalu muncul keinginan untuk membeli produk tersebut (Kotler \& Armstrong, 2008:178). Menurut (Schiffman et al. 2010:23) niat beli adalah sesuatu kekuatan psikologis yang ada di dalam individu yang berdampak pada sebuah tindakan. Purchase intention (niat beli) dianggap sebagai pengukuran kemungkinan konsumen membeli produk tertentu dimana tingginya minat beli berdampak pada kemungkinan yang cukup besar dalam terjadinya keputusan pembelian. Adidas Yeezy adalah hasil kolaborasi antara Adidas dengan seorang musisi rapper bernama Kanye West yang dirilis pada tahun 2015. Adidas dan Kanye West sepakat untuk memproduksi sepatu Adidas Yeezy dengan kuantitas yang terbatas. Keterbatasan produk yang ditawarkan berdampak pada meningkatnya niat beli masyarakat pada sepatu Adidas Yeezy. Tingginya permintaan akan sepatu Adidas Yeezy membuat harga penjualan kembali sepatu ini melonjak secara drastis. Meningkatnya harga sepatu ini tidak menurunkan niat masyarakat untuk membeli sepatu Adidas Yeezy. Data terakhir pada tahun 2018, dalam situs perkembangan fashion www.highsnobiety.com (2019) menampilkan data flutuasi rata-rata harga penjualan kembali sepatu Adidas Yeezy.

AVERAGE RESELL PRICE OF YEEZYS
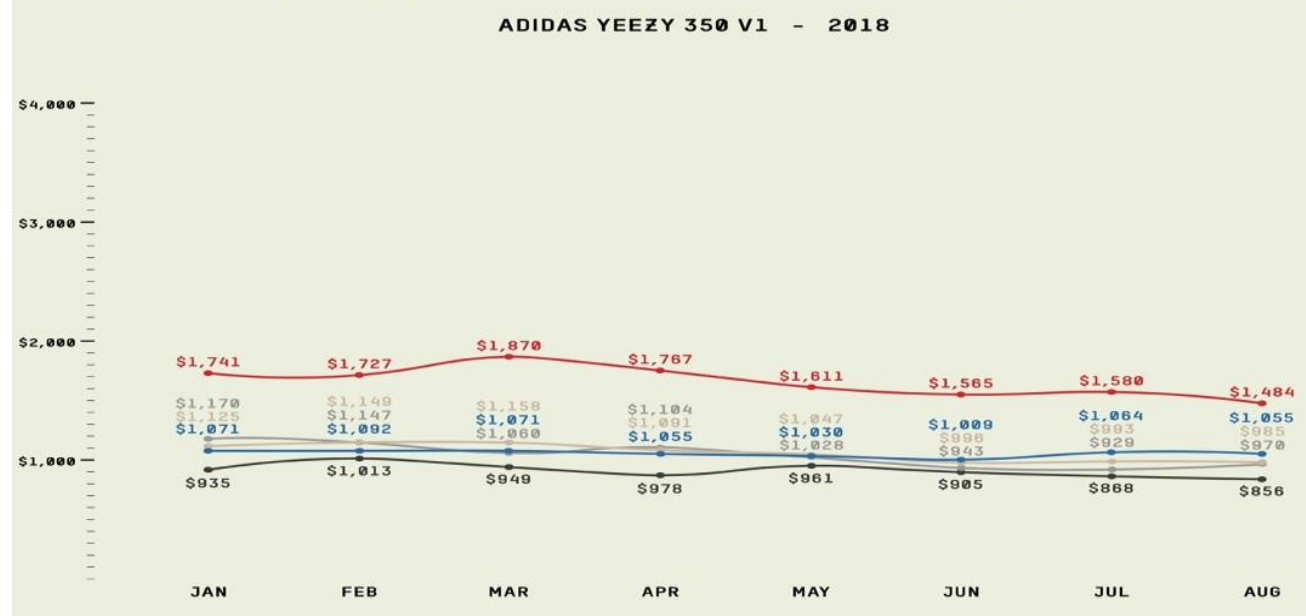

Gambar 1. Harga Rata-Rata Penjualan Kembali Adidas Yeezy Tahun 2018 Sumber: www.highsnobiety.com, 2019 
Data ini mengungkapkan bahwa pada tahun 2018, harga penjualan kembali Adidas Yeezy mencapai $\$ 1.870$ dari harga toko hanya sebesar $\$ 200$. Hal ini menunjukkan bahwa niat beli masyarakat akan Adidas Yeezy sangat tinggi. Pada tahun 2019, tiga model dari sepatu Adidas Yeezy dinobatkan sebagai sepatu dengan permintaan pasar yang tinggi. Tingginya purchase intention suatu produk dapat dipengaruhi oleh brand awareness produk tersebut (Orlando, 2015).

\section{TOP 10 SNEAKERS BY MARKET SHARE}
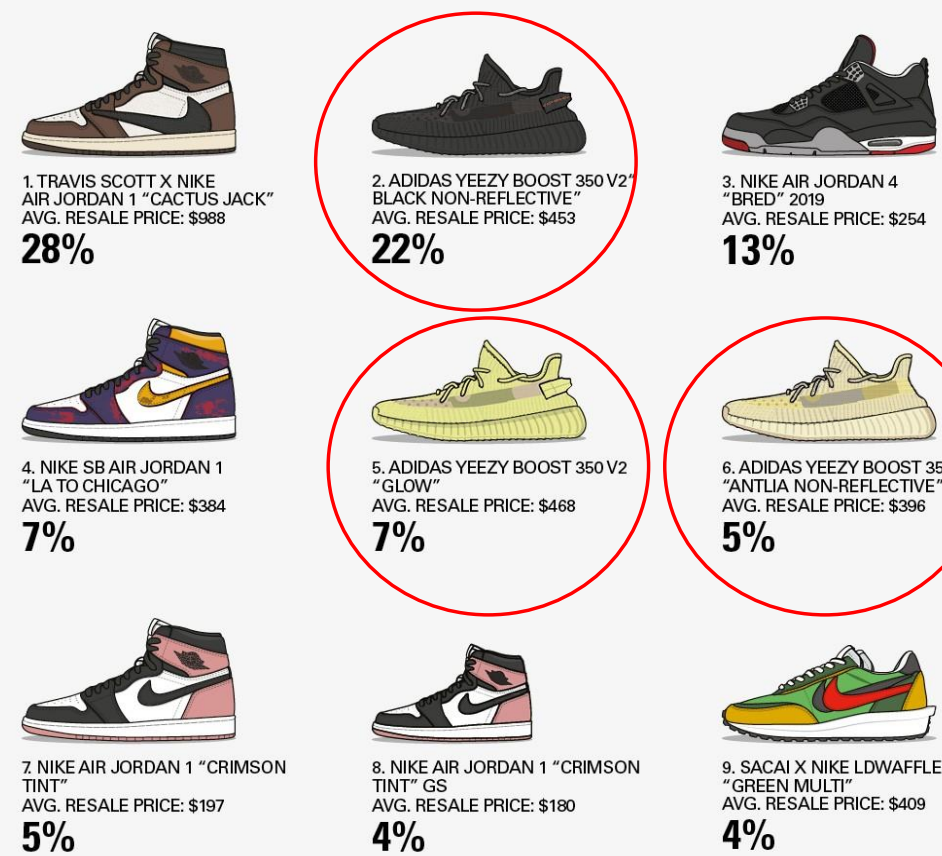

$13 \%$
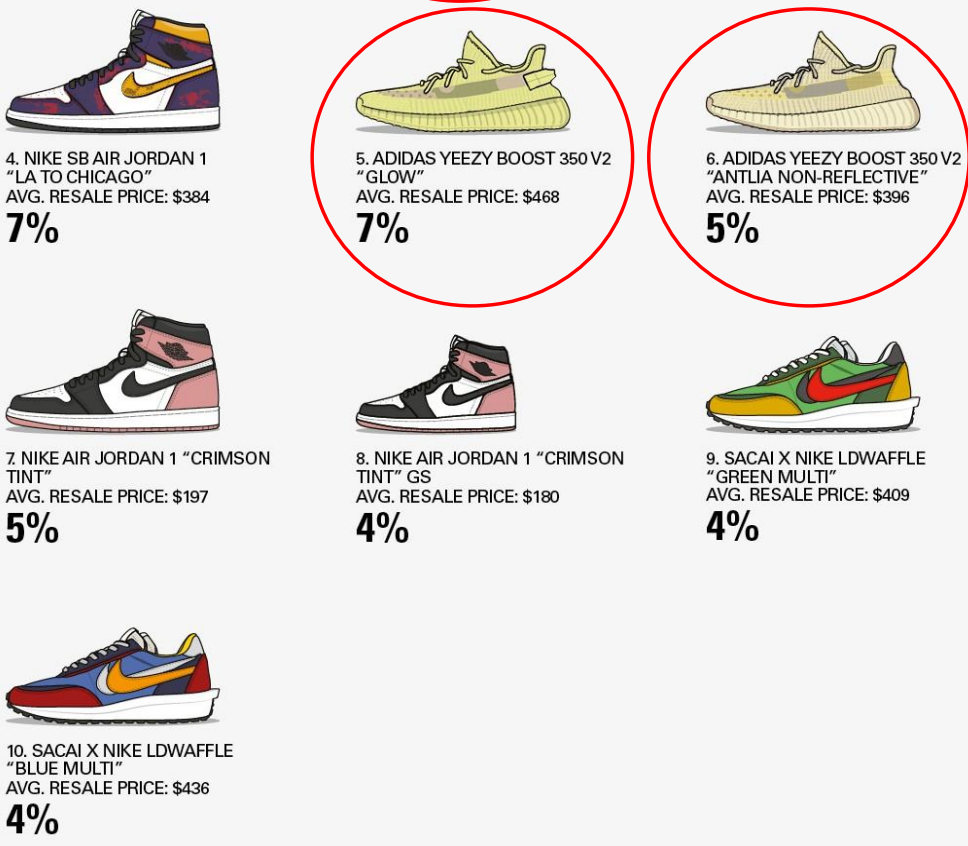

Gambar 2. Top 10 Sneakers By Market Share Tahun 2019

Sumber: www.highsnobiety.com, 2019

Brand awareness adalah kapasitas konsumen untuk mengenali sebuah merek diantara merek lain (Akhmedov, 2016). Kanye West resmi berkolaborasi dengan Adidas pada Februari tahun 2015 dengan menciptakan Adidas Yeezy. Brand awareness sepatu Adidas Yeezy meningkat ketika media massa meliput acara fashion show yang diadakan oleh Kanye West dalam rangka merilis sepatu Adidas Yeezy. Sepatu Adidas Yeezy masuk ke Indonesia pada awal tahun 2016 dan menciptakan brand awareness yang cukup tinggi. Ini ditandai dengan antusias masyarakat Indonesia yang mengantre untuk membeli sepatu Adidas Yeezy di hari 
pertama perilisannya di Mall Grand Indonesia, Jakarta. Hal ini dimuat dalam berbagai koran online nasional di Indonesia antara lain: Kompas.com (2019), Detik.com (2016), dan Cnbcindonesia.com (2019). Dalam hal brand awareness, pada situs www.topbrand-award.com (2019) perusahaan Adidas menduduki peringkat pertama hasil survei Top Brand Index 2016-2019 untuk kategori sepatu olahraga. Situs www.topbrand-award.com (2019) merupakan sebuah situs yang memuat informasi tentang penilaian suatu merek yang diperoleh dari hasil survei berskala nasional. Untuk selanjutnya dapat dilihat pada Tabel 1.

Tabel 1.

Peringkat Top Brand Index Kategori Sepatu Olahraga Tahun 2016-2019

\begin{tabular}{|c|c|c|c|c|c|c|c|c|c|c|c|c|}
\hline \multicolumn{4}{|c|}{ Tahun 2016} & \multicolumn{3}{|c|}{ Tahun 2017} & \multicolumn{3}{|c|}{ Tahun 2018} & \multicolumn{3}{|c|}{ Tahun 2019} \\
\hline $\begin{array}{c}\text { No } \\
\text {. }\end{array}$ & $\begin{array}{c}\text { Mere } \\
\mathbf{k}\end{array}$ & $\begin{array}{c}\text { TB } \\
\text { I } \\
(\%) \\
)\end{array}$ & Ket & Merek & $\begin{array}{c}\text { TB } \\
\text { I } \\
(\% \\
)\end{array}$ & Ket & Merek & $\begin{array}{c}\text { TB } \\
\text { I } \\
(\% \\
)\end{array}$ & Ket & Merek & $\begin{array}{c}\text { TB } \\
\text { I } \\
(\%) \\
)\end{array}$ & Ket \\
\hline 1 & $\begin{array}{l}\text { Adida } \\
\mathrm{s}\end{array}$ & $\begin{array}{c}37 . \\
4\end{array}$ & $\begin{array}{c}\text { TO } \\
\mathrm{P}\end{array}$ & Adidas & $\begin{array}{c}38 . \\
2\end{array}$ & $\begin{array}{c}\text { TO } \\
\mathrm{P}\end{array}$ & Adidas & $\begin{array}{c}37 . \\
6\end{array}$ & $\begin{array}{c}\text { TO } \\
P\end{array}$ & Adidas & $\begin{array}{c}37 . \\
0\end{array}$ & $\begin{array}{c}\text { TO } \\
\mathrm{P}\end{array}$ \\
\hline 2 & Nike & $\begin{array}{c}29 . \\
6\end{array}$ & $\begin{array}{c}\text { TO } \\
\mathrm{P}\end{array}$ & Nike & $\begin{array}{c}32 . \\
2\end{array}$ & $\begin{array}{c}\text { TO } \\
\mathrm{P}\end{array}$ & Nike & $\begin{array}{c}25 . \\
6\end{array}$ & $\begin{array}{c}\text { TO } \\
\mathrm{P}\end{array}$ & Nike & $\begin{array}{c}21 . \\
1\end{array}$ & $\begin{array}{c}\text { TO } \\
\mathrm{P}\end{array}$ \\
\hline 3 & $\begin{array}{c}\text { Reebo } \\
\mathrm{k}\end{array}$ & 3.7 & & $\begin{array}{c}\text { Covers } \\
\text { e }\end{array}$ & 3.6 & & $\begin{array}{c}\text { Reebo } \\
\mathrm{k}\end{array}$ & 6.2 & & $\begin{array}{c}\text { Ardile } \\
\mathrm{S}\end{array}$ & 8.3 & \\
\hline 4 & Bata & 3.6 & & Eagle & 3.3 & & $\underset{\mathrm{S}}{\text { Ardile }}$ & 5.2 & & $\begin{array}{c}\text { Reebo } \\
\mathrm{k}\end{array}$ & 6.3 & \\
\hline 5 & Eagle & 3.0 & & $\begin{array}{c}\text { Reebo } \\
\mathrm{k}\end{array}$ & 3.3 & & $\begin{array}{c}\text { Diador } \\
\text { a }\end{array}$ & 4.6 & & $\begin{array}{c}\text { Diador } \\
\text { a }\end{array}$ & 2.9 & \\
\hline
\end{tabular}

Sumber: www.topbrand-award.com (2019)

Indikator pemberian posisi ini dilihat dari 3 aspek yaitu mind share, market share dan commitment share. Mind share menunjukkan kekuatan merek di dalam benak konsumen dari masing-masing produk. Market share menunjukkan kekuatan merek di pasar tertentu dalam hal perilaku pembelian aktual konsumen. Commitment share menunjukkan kekuatan merek dalam mendorong konsumen untuk membeli merek di masa depan. Hasil survei menunjukkan bahwa perusahaan Adidas memiliki awareness yang cukup kuat, terbukti dengan mendapatkan predikat pertama dalam kurun waktu 4 tahun. Keberhasilan membangun brand awareness sangat ditentukan oleh persepsi konsumen terhadap celebrity endorser yang menjadi ikon produk karena konsumen cenderung mengevaluasi informasi yang diberikan oleh ikon atau selebriti dari produk tersebut (Aaker, 2013:206).

Celebrity endorser adalah penggunaan narasumber (source) sebagai figur yang menarik atau populer dalam iklan, hal tersebut merupakan cara yang cukup kreatif untuk menyampaikan pesan agar pesan yang disampaikan dapat memperoleh perhatian yang lebih tinggi serta dapat diingat (Kotler \& Keller, 2008:470). Perusahaan Adidas merupakan salah satu perusahaan yang mempromosikan produknya dengan menggunakan celebrity endorser. Perusahaan Adidas sering mempromosikan produknya menggunakan celebrity endorser seperti atlet, artis, musisi, dan bintang film. Pada sepatu Adidas Yeezy, Adidas 
menggunakan Kanye West sebagai celebrity endorser dari produk sepatu Yeezy. Penggunaan celebrity endorser menjadi salah satu strategi pemasaran kreatif yang dilakukan dalam beriklan yang dapat menarik perhatian konsumen (Foong \& Yazdanifard, 2014).

Penelitian yang dilakukan oleh Putra \& Sulistyawati (2015) menyatakan bahwa celebrity endorser berpengaruh positif signifikan terhadap purchase intention. Hasil penelitian yang sama juga diungkapkan oleh Foong \& Yazdanifard (2014) dan Rajasekar (2018) yang menyatakan bahwa celebrity endorser berpengaruh positif dan signifikan terhadap purchase intention. Pendapat berbeda didapat dari hasil penelitian oleh Stephanie et al. (2013) yang menyatakan bahwa seorang celebrity endorser yang terkenal dan berpenampilan menarik tidak memiiki pengaruh terhadap purchase intention suatu produk. Roshan \& Sudiksa (2019) mengungkapkan bahwa seorang celebrity endorser yang terlibat dalam sebuah kasus kriminal atau skandal akan menyebabkan reaksi negatif dari konsumen sehingga berdampak pada purchase intention suatu produk.

Feiz et al. (2018) menyatakan bahwa kekuatan celebrity endorser berpengaruh positif dan signifikan terhadap brand awareness pada iklan sepeda motor Honda Beat. Hasil penelitian yang sama juga diungkapkan oleh Pramesti et al. (2017), Paramhita \& Purnami (2018), dan Sintani (2016) yang menyatakan bahwa celebrity endorser berpengaruh postif dan signifikan terhadap brand awareness. Kahle \& Homer (2016) menyatakan bahwa seorang celebrity endorser dipasangkan dengan produk yang berhubungan dengan daya tariknya akan meningkatkan brand awareness dari produk tersebut.

Penelitian yang dilakukan oleh Purnomo (2018) menyatakan bahwa brand awareness memiliki pengaruh positif signifikan terhadap purchase intention konsumen Herbalife di Surabaya. Orlando (2015) menyatakan bahwa brand awareness berpengaruh positif terhadap purchase intention sepeda motor Kawasaki Ninja. Paramhita \& Purnami (2018) dan Setiawan (2018) menyatakan bahwa brand awareness mampu memediasi pengaruh celebrity endorser terhadap purchase intention.

Sepatu Adidas Yeezy merupakan hasil kolaborasi dari Adidas dan Kanye West yang dirilis pada tahun 2015. Pada tahun 2018, harga penjualan kembali sepatu Adidas Yeezy melonjak lima kali lipat dari harga toko. Tingginya niat beli masyarakat pada sepatu Adidas Yeezy ini tidak terlepas dari kontribusi celebrity endorser Adidas Yeezy yaitu Kanye West. Berdasarkan fenomena yang telah dipaparkan tersebut maka penulis tertarik untuk meneliti dan mengambil judul "Peran Brand Awareness Dalam Memediasi Pengaruh Celebrity Endorser Terhadap Purchase Intention Sepatu Adidas Yeezy di Provinsi Bali.

Feiz et al. (2018) mengungkapkan bahwa penggunaan celebrity endorser berpengaruh positif signifikan terhadap brand awareness pada iklan sepeda motor Honda beat. Hal yang sama juga diungkapkan oleh Pramesti et al. (2017) menyatakan penggunaan celebrity endorser berpengaruh positif terhadap brand awareness Georgio Store. Paramhita \& Purnami (2018) menyatakan bahwa celebrity endorser berpengaruh positif dan signifikan terhadap brand awareness. Sintani (2016) menyatakan bahwa penggunaan celebrity endorser berpengaruh positif terhadap brand awareness. Hasil penelitian yang dilakukan oleh Ateke \& 
Onwujiariri (2016) dan Ugwuanyi et al. (2018) menyatakan bahwa celebrity endorser berpengaruh positif dan signifikan terhadap brand awareness. Menurut Keller (2003:178) dalam mengingat konsumen dibutuhkan peran selebriti, maka dari itu sangat penting dan relevan untuk memahami peran celebrity endorser dalam menghasilkan brand awareness. Berdasarkan hasil penelitian sebelumnya, dapat dibangun hipotesis sebagai berikut.

$\mathrm{H}_{1}$ : Celebrity Endorser berpengaruh positif dan signifikan terhadap Brand Awareness

Selebriti adalah tokoh (aktor, penghibur, atlet) yang dikenal masyarakat karena prestasinya di dalam bidang-bidang yang berbeda dari golongan produk yang didukung (Alatas \& Tarbani, 2018). Hasil penelitian dari Putra \& Sulistyawati (2015) menyatakan bahwa celebrity endorser berpengaruh positif terhadap niat beli sepatu basket Nike Kobe. Roshan \& Sudiksa (2019) mengungkapkan hal yang sama bahwa penggunaan celebrity endorser berpengaruh positif dan signifikan terhadap purchase intention produk lipstick dari Wardah.

Hasil serupa juga disebutkan pada penelitian yang dilakukan oleh Alatas \& Tarbani (2018), Foong \& Yazdanifard (2014), dan Rajasekar (2018) yang menyebutkan bahwa celebrity endorser berpengaruh signifikan positif terhadap purchase intention. Hasil penelitian yang dilakukan oleh Hani et al. (2018), Priyankara et al. (2017), Abbas et al. (2018), dan Chin et al. (2017) menyatakan bahwa celebrity endorser berpengaruh positif dan signifikan terhadap purchase intention. Hasil penelitian yang berbeda diungkapkan oleh Stephanie et al. (2013) yang menyatakan bahwa celebrity endorser tidak berpengaruh signifikan terhadap purchase intention. Berdasarkan hasil penelitian sebelumnya, dapat dibangun hipotesis sebagai berikut.

$\mathrm{H}_{2}$ : Celebrity Endorser berpengaruh positif dan signifikan terhadap Purchase Intention

Shahid et al. (2017) mendefinisikan brand awareness atau kesadaran merek adalah tingkat primitif pengetahuan merek, melibatkan setidaknya identifikasi nama merek atau struktur yang telah dikembangkan pada informasi rinci. Penelitian yang dilakukan Purnomo (2018) menyatakan bahwa brand awareness berpengaruh positif signifikan terhadap purchase intention konsumen Herbalife di Surabaya. Eliasari \& Sukaatmadja (2017) mengungkapkan bahwa brand awareness berpengaruh positif terhadap purchase intention. Orlando (2015) menyatakan bahwa brand awareness berpengaruh positif terhadap purchase intention sepeda motor Kawasaki Ninja. Dewi \& Sulistyawati (2018) menyatakan bahwa brand awareness berpengaruh positif terhadap purchase intention (niat beli) produk pasta gigi Sensodyne di Kota Denpasar. Hasil-hasil penelitian tersebut menunjukkan bahwa brand awareness mampu meningkatkan purchase intention pada konsumen. Berdasarkan penelitian sebelumnya, dapat dibangun hipotesis sebagai berikut.

$\mathrm{H}_{3}$ : Brand Awareness berpengaruh positif dan signifikan terhadap Purchase Intention

Paramhita \& Purnami (2018) menyatakan bahwa brand awareness mampu memediasi pengaruh celebrity endorser terhadap purchase intention calon pengguna Bukalapak.com. Hasil penelitian yang sama juga diungkapakan oleh Setiawan (2018) yang menyatakan bahwa brand awareness mampu memediasi 
pengaruh celebrity endorser terhadap purchase intention pada produk Green Tea Esprecielo. Berdasarkan hasil penelitian sebelumnya dapat dibangun hipotesis sebagai berikut.

$\mathrm{H}_{4}$ : Brand Awareness memediasi pengaruh Celebrity Endorser terhadap Purchase Intention

\section{METODE PENELITIAN}

Lokasi penelitian ini dilakukan di Provinsi Bali. Alasan memilih lokasi penelitian di Provinsi Bali adalah Provinsi Bali memiliki 5 outlet Adidas yang menyediakan berbagai produk Adidas. Outlet-outlet Adidas ini tersebar di Beachwalk Shopping Centre, Lippo Mall Kuta, Park 23, dan Adidas Factory Outlet Teuku Umar. Berdasarkan data dari customer service, outlet Adidas di Beachwalk Shopping Center yang menyatakan bahwa pengunjung toko terdiri dari penduduk domestik dan wisatawan mancanegara. Penduduk domestik yang berkunjung ke outlet Adidas Beachwalk mayoritas berdomisili di Provinsi Bali antara lain: Denpasar, Badung, Gianyar, Tabanan, Klungkung, Karangasem, Buleleng, Bangli, dan Jembrana. Berdasarkan alasan-alasan tersebut maka Provinsi Bali dipilih sebagai lokasi penelitian untuk meneliti peran brand awareness memediasi pengaruh celebrity endorser terhadap purchase intention.

Populasi penelitian ini adalah masyarakat yang belum pernah membeli produk sepatu Adidas Yeezy di Provinsi Bali. Teknik non-probability sampling yang dipilih adalah purposive sampling yaitu teknik penentuan sampel dengan pertimbangan tertentu. Maka ukuran sampel sebaiknya dikalikan 5-10 dibandingkan dengan jumlah variabel di dalam studi. Penelitian ini menggunakan 12 indikator sehingga dengan menggunakan estimasi berdasarkan jumlah parameter dapat diperoleh ukuran sampel sebesar $12 \times 5=60$ responden dimana peneliti menggunakan ukuran 5 kali lebih besar. Dalam penelitian ini sampel yang digunakan adalah sebesar 60 responden.

Analisis jalur digunakan untuk menentukan pola hubungan antara tiga atau lebih dan tidak dapat digunakan untuk mengkonfirmasi atau mengolah hipotesis. Analisis jalur digunakan untuk menganalisis pola hubungan antar variabel dengan tujuan untuk mengetahui pengaruh langsung maupun tidak langsung seperangkat variabel bebas terhadap variabel terikat (Riduwan \& Kuncoro, 2011:2). Dasar perhitungan koefisien jalur adalah analisis korelasi dan regresi dan dalam perhitungan menggunakan software dengan program SPSS for windows.

\section{HASIL DAN PEMBAHASAN}

Responden pada penelitian ini berjumlah 60 orang sesuai dengan ukuran sampel yang digunakan. Responden pada penelitian ini merupakan orang-orang yang berdomisili di Provinsi Bali diantaranya, Denpasar, Badung, Gianyar, Tabanan, Klungkung, Karangasem, Buleleng, Bangli, dan Jembrana. Pada penelitian ini pencarian responden menggunakan kuesioner yang disebarkan secara elektronik atau yang disebut dengan survei daring (online survey) melalui berbagai sosial media seperti Instagram, Facebook Fanpage, Whatsapp, dan Line. Responden 
penelitian akan digambarkan dengan menyajikan karakteristik responden yang terdiri dari jenis kelamin, usia, pendidikan terakhir dan pekerjaan yang disajikan pada Tabel 2 berikut ini:

Tabel 2.

Karakteristik Responden

\begin{tabular}{|c|c|c|c|c|}
\hline No & Karakteristik & Klasifikasi & $\begin{array}{l}\text { Jumlah } \\
\text { Responden } \\
\text { (Orang) }\end{array}$ & $\begin{array}{c}\text { Persentase } \\
(\%)\end{array}$ \\
\hline \multirow[t]{4}{*}{1} & Jenis Kelamin & Laki-laki & 34 & 56,7 \\
\hline & & Perempuan & 26 & 43,3 \\
\hline & & umlah & 60 & 100 \\
\hline & & 18-22 Tahun & 31 & 51,7 \\
\hline \multirow[t]{5}{*}{2} & Usia & 23-27 Tahun & 14 & 23,3 \\
\hline & & 28-32 Tahun & 15 & 25,0 \\
\hline & & Jumlah & 60 & 100 \\
\hline & & SMA/SMK Sederajat & 31 & 51,7 \\
\hline & & Diploma & 4 & 6,7 \\
\hline \multirow[t]{6}{*}{3} & Tingkat & S1 & 21 & 35,0 \\
\hline & & S2 & 3 & 5,0 \\
\hline & & S3 & 1 & 1,7 \\
\hline & & Jumlah & 60 & 100 \\
\hline & & Pelajar/Mahasiswa & 29 & 48,3 \\
\hline & & Wiraswasta & 6 & 10,0 \\
\hline \multirow{5}{*}{4} & . D. & Pegawai Negeri Sipil & 2 & 3,3 \\
\hline & Jenıs Pekerjaan & Pegawai Swasta & 19 & 31,7 \\
\hline & & TNI/POLRI & 1 & 1,7 \\
\hline & & Lainnya & 3 & 5,0 \\
\hline & & Jumlah & 60 & 100 \\
\hline
\end{tabular}

Sumber: Data diolah, 2019

Tabel 2. menunjukkan karakteristik responden dalam penelitian ini berdasarkan jenis kelamin didominasi oleh laki-laki sebanyak 34 orang dengan persentase sebesar 56,7 persen dan sisanya perempuan sebanyak 26 orang dengan persentase sebesar 43,3 persen. Karakteristik berdasarkan usia, menunjukkan bahwa mayoritas responden berusia pada rentang usia 18-22 tahun sebanyak 31 orang dengan persentase 51,7 persen, usia 23-27 tahun sebanyak 14 orang dengan persentase sebesar 23,3 persen kemudian usia 28-32 tahun sebanyak 15 orang dengan presentase sebesar 25 persen.

Karakteristik responden berdasarkan pendidikan terakhir didominasi oleh SMA/SMK Sederajat sebanyak 31 orang dengan persentase 51,7 persen, pendidikan terakhir Diploma sebanyak 4 orang dengan presentase 6,7 persen, pendidikan terakhir S1 sebanyak 21 orang dengan persentase 35 persen, pendidikan terakhir S2 sebanyak 3 orang dengan presentase sebesar 5 persen serta pendidikan terakhir S3 sebanyak 1 orang dengan persentase 1,7 persen.

Karakteristik responden berdasarkan jenis pekerjaan didominasi oleh responden yang berprofesi sebagai pelajar/mahasiswa sebanyak 29 orang dengan persentase 48,3 persen, responden yang berprofesi sebagai wiraswasta sebanyak 6 orang dengan presentase 10 persen, responden yang berprofesi sebagai pegawai negeri sipil sebanyak 2 orang atau 3,3 persen, kemudian responden yang berprofesi sebagai pegawai swasta sebanyak 19 orang dengan persentase 31,7 persen, 
selanjutnya responden yang berprofesi sebagai TNI/POLRI sebanyak 1 orang dengan persentase 1,7 persen, serta responden profesi lainnya sebanyak 3 orang dengan persentase 5 persen.

Uji validitas adalah sebuah instrumen yang bertujuan memeriksa apakah kuesioner sebagai instrumen penelitian sudah tepat untuk mengukur apa yang seharusnya di ukur. Suatu instrumen dikatakan valid apabila memiliki koefisien korelasi antara butir dengan skor total dalam instrumen tersebut lebih besar dari 0,30 dengan tingkat kesalahan Alpha 0,50. Tabel 3 berikut menyajikan hasil validitas instrumen penelitian.

Tabel 3.

Hasil Uji Validitas

\begin{tabular}{|c|c|c|c|c|}
\hline No. & Variabel & $\begin{array}{c}\text { Item } \\
\text { Pernyataan }\end{array}$ & $\begin{array}{c}\text { Korelasi Item } \\
\text { Total }\end{array}$ & Keterangan \\
\hline \multirow[t]{4}{*}{1.} & Celebrity Endorser $(\mathrm{X})$ & $\mathrm{X}_{1.1}$ & 0,981 & Valid \\
\hline & & $\mathrm{X}_{1.2}$ & 0,981 & Valid \\
\hline & & $\mathrm{X}_{1.3}$ & 0,960 & Valid \\
\hline & & $\mathrm{X}_{1.4}$ & 0,974 & Valid \\
\hline \multirow[t]{4}{*}{2.} & Brand Awareness (Y1) & $\mathrm{Y}_{1.1}$ & 0,942 & Valid \\
\hline & & $\mathrm{Y}_{1.2}$ & 0,917 & Valid \\
\hline & & $\mathrm{Y}_{1.3}$ & 0,954 & Valid \\
\hline & & $\mathrm{Y}_{1.4}$ & 0,896 & Valid \\
\hline \multirow[t]{4}{*}{3.} & Purchase Intention (Y2) & $\mathrm{Y}_{2.1}$ & 0,894 & Valid \\
\hline & & $\mathrm{Y}_{2.2}$ & 0,905 & Valid \\
\hline & & $\mathrm{Y}_{2.3}$ & 0,871 & Valid \\
\hline & & $Y_{2.4}$ & 0,910 & Valid \\
\hline
\end{tabular}

Sumber: Data diolah, 2019

Hasil uji pada Tabel 3. menujukkan bahwa seluruh instrumen penelitian yang digunakan untuk mengukur variabel Celebrity Endorser, Brand Awareness dan Purchase Intention memiliki nilai koefisien korelasi dengan skor total seluruh item pernyataan lebih besar 0,30 dengan signifikansi kurang dari 0,05. Hal ini menunjukkan bahwa butir-butir pernyataan dalam instrumen penelitian tersebut valid dan layak digunakan sebagai instrumen penelitian.

Uji reliabilitas menunjukkan sejauh mana suatu alat pengukur dapat dipercaya atau dapat diandalkan. Apabila suatu alat pengukur dipakai dua kali untuk mengukur gejala yang sama dan hasil pengukuran yang diperoleh relatif konsisten, maka alat pengukur tersebut reliabel. Suatu instrumen dapat dikatakan reliabel apabila nilai Cronbach's Alpha $\geq 0,60$. Hasil pengujian reliabilitas instrumen dapat dilihat pada Tabel 4.

Tabel 4.

Hasil Uji Realibilitas

\begin{tabular}{clcc}
\hline No. & \multicolumn{1}{c}{ Variabel } & Cronbach's Alpha & Keterangan \\
\hline 1 & Celebrity Endorser $(\mathrm{X})$ & 0,982 & Reliabel \\
2 & Brand Awareness $\left(\mathrm{Y}_{1}\right)$ & 0,945 & Reliabel \\
3 & Purchase Intention $\left(\mathrm{Y}_{2}\right)$ & 0,916 & Reliabel \\
\hline Sumber: & Data diolah, 2019 & &
\end{tabular}

Hasil uji reliabilitas pada Tabel 4. menunjukkan bahwa ketiga instrumen penelitian memiliki koefisien Cronbach's Alpha lebih dari 0,60. Hal ini dapat 
dikatakan, apabila semua variabel instrumen penelitian nilai koefisiennya $>0,60$ maka instrumen tersebut adalah reliabel, sehingga dapat digunakan dalam penelitian ini.

Uji normalitas bertujuan untuk mengetahui apakah residual dari model regresi yang dibuat berdistribusi normal atau tidak. Untuk menguji apakah data yang digunakan normal atau tidak dapat dilakukan dengan menggunakan uji Kolmogorov Smirnov. Apabila koefisien Asymp. Sig. (2-tailed) lebih besar dari 0,05 maka data tersebut dikatakan berdistribusi normal.

Tabel 5.

Hasil Uji Normalitas Struktur 1

\begin{tabular}{lcc}
\hline & & Unstandardized Residual \\
\hline $\mathrm{N}$ & 60 \\
& Kolmogorov-Smirnov Z & 0,629 \\
Asymp.Sig.(2-tailed) & 0,824 \\
\hline Sumber: Data diolah 2019
\end{tabular}

Sumber: Data diolah, 2019

Berdasarkan Tabel 5. dapat dilihat bahwa nilai Kolmogorov Smirnov (K-S) sebesar 0,629, sedangkan nilai Asymp. Sig. (2-tailed) sebesar 0,824. Hasil tersebut mengindikasikan bahwa model persamaan regresi tersebut berdistribusi normal karena nilai Asymp. Sig. (2-tailed) lebih besar dari nilai alpha 0,05.

Tabel 6.

Hasil Uji Normalitas Struktur 2

\begin{tabular}{lcc}
\hline & Unstandardized Residual \\
\hline $\mathrm{N}$ & 60 \\
& Kolmogorov-Smirnov $Z$ & 0,581 \\
& Asymp.Sig.(2-tailed) & 0,888 \\
\hline
\end{tabular}

Sumber: Data diolah, 2019

Berdasarkan Tabel 6. dapat dilihat bahwa nilai Kolmogorov Smirnov (K-S) sebesar 0,581, sedangkan nilai Asymp. Sig. (2-tailed) sebesar 0,888. Hasil tersebut mengindikasikan bahwa model persamaan regresi tersebut berdistribusi normal karena nilai Asymp. Sig. (2-tailed) lebih besar dari nilai alpha 0,05.

Adanya multikolinearitas dapat dilihat dari nilai tolerance atau variance inflation factor (VIF). Jika nilai tolerance lebih dari $10 \%$ atau VIF Kurang dari 10, maka dikatakan tidak ada multikolinearitas.

Tabel 7.

Hasil Uji Multikolinearitas

\begin{tabular}{ccc}
\hline \multicolumn{1}{c}{ Variabel } & Tolerance & VIF \\
\hline Celebrity Endorser $(\mathrm{X})$ & 0,558 & 1,793 \\
Brand Awareness $\left(\mathrm{Y}_{1}\right)$ & 0,558 & 1,793 \\
\hline
\end{tabular}

Sumber: Data diolah, 2019

Berdasarkan Tabel 7. dapat dilihat bahwa nilai tolerance dan VIF dari variabel celebrity endorser dan brand awareness menunjukkan nilai tolerance untuk setiap variabel lebih besar dari 10\% dan nilai VIF lebih kecil dari 10 yang berarti model persamaan regresi bebas dari multikolinearitas. 
Uji yang menilai apakah ada ketidaksamaan varian dari residual untuk semua pengamatan pada model regresi linear. Apabila asumsi heteroskedastisitas tidak terpenuhi, maka model regresi dinyatakan tidak valid sebagai alat peramalan dan pengujian ini dilakukan dengan Uji Glejser. Jika nilai signifikansinya di atas 0,05 maka tidak mengandung gejala heteroskedastisitas.

Tabel 8.

Hasil Uji Heteroskedastisitas Struktur 1

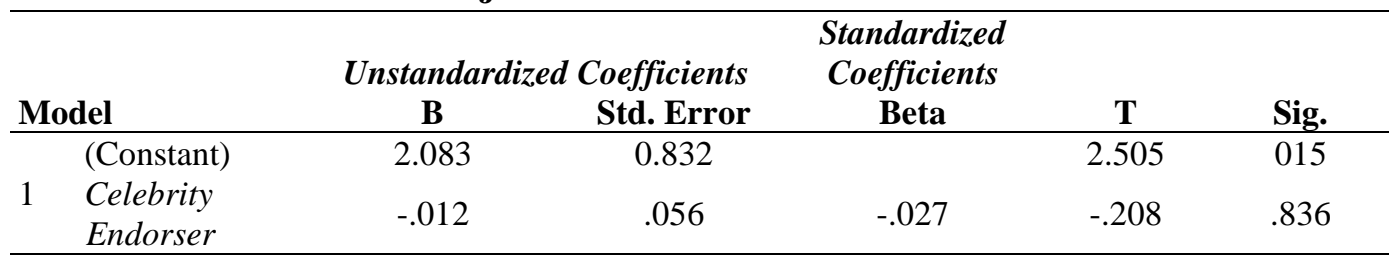

Sumber: Data diolah, 2019

Pada Tabel 8. dapat dilihat bahwa nilai signifikansi dari variabel celebrity endorser sebesar 0,836. Nilai tersebut lebih besar dari 0,05 yang berarti tidak terdapat pengaruh antara variabel bebas terhadap absolute residual. Sehingga model yang dibuat tidak mengandung gejala heteroskedastisitas.

Tabel 9.

Hasil Uji Heteroskedastisitas Struktur 2

\begin{tabular}{|c|c|c|c|c|c|c|}
\hline \multirow{2}{*}{\multicolumn{2}{|c|}{ Model }} & \multicolumn{2}{|c|}{$\begin{array}{l}\text { Unstandardized } \\
\text { Coefficients }\end{array}$} & \multirow{2}{*}{$\begin{array}{c}\text { Standardized } \\
\text { Coefficients } \\
\text { Beta } \\
\end{array}$} & \multirow[b]{2}{*}{$\mathbf{T}$} & \multirow[b]{2}{*}{ Sig. } \\
\hline & & B & Std. Error & & & \\
\hline \multirow[t]{3}{*}{2} & (Constant) & 3.296 & .854 & & 3.858 & .000 \\
\hline & $\begin{array}{l}\text { Celebrity } \\
\text { Endorser }\end{array}$ & -.018 & .068 & -.046 & -.270 & .788 \\
\hline & $\begin{array}{l}\text { Brand } \\
\text { Awareness }\end{array}$ & -.092 & .070 & -.224 & -1.308 & .196 \\
\hline
\end{tabular}

Sumber: Data diolah, 2019

Pada Tabel 9. dapat dilihat bahwa nilai signifikansi dari variabel celebrity endorser sebesar 0,788, dan variabel brand awareness sebesar 0,196. Nilai tersebut lebih besar dari 0,05 yang berarti tidak terdapat pengaruh antara variabel bebas terhadap absolute residual. Sehingga model yang dibuat tidak mengandung gejala heteroskedastisitas.

Tabel 10.

Hasil Analisis Jalur Persamaan Regresi 1

\begin{tabular}{|c|c|c|c|c|c|c|}
\hline \multirow[t]{2}{*}{ Model } & & \multicolumn{2}{|c|}{$\begin{array}{l}\text { Unstandardized } \\
\text { Coefficients }\end{array}$} & \multirow{2}{*}{$\begin{array}{c}\text { Standardized } \\
\text { Coefficients } \\
\text { Beta } \\
\end{array}$} & \multirow[t]{2}{*}{$\mathbf{T}$} & \multirow[t]{2}{*}{ Sig. } \\
\hline & & B & Std. Error & & & \\
\hline 1 & (Constant) & 5.405 & 1.429 & & 3.783 & 0000 \\
\hline & Celebrity Endorser & 0.647 & 0.095 & 0.665 & 6.783 & 0.000 \\
\hline $\mathrm{R} 1^{2}$ & $: 0,442$ & & & & & \\
\hline F statistic & : 46.012 & & & & & \\
\hline Sig. F & $: 0,000$ & & & & & \\
\hline
\end{tabular}


Pengujian data dalam penelitian ini menggunakan teknik analisis jalur (Path Analysis), dimana analisis jalur merupakan perluasan dari analisis regresi linear berganda untuk menguji hubungan kausalitas antara 2 variabel atau lebih. Perhitungan koefisien jalur dilakukan dengan menggunakan SPSS 20. Pada Tabel 10 disajikan hasil dari pengolahan data untuk persamaan regresi 1 . Berdasarkan hasil analisis jalur persamaan regresi 1 seperti yang disajikan pada Tabel 10, maka persamaan strukturnya adalah sebagai berikut:

$$
\mathrm{Y}_{1}=0,665 \mathrm{X}
$$

Nilai $\beta_{1}$ adalah sejumlah 0,665 memiliki celebrity endorser berpengaruh positif terhadap brand awareness, hal ini menunjukkan bahwa apabila variabel celebrity endorser meningkat maka brand awareness sepatu Adidas Yeezy di Provinsi Bali akan meningkat sebanyak 0,665. Besarnya pengaruh variabel bebas terhadap variabel terikat yang ditunjukkan oleh nilai determinasi total ( $\mathrm{R}$ square) sebesar 0,442 mempunyai arti bahwa sebesar 44,2 persen variasi brand awareness dipengaruhi oleh variasi celebrity endorser, sedangkan sisanya sebesar 55,8 persen dijelaskan oleh faktor lain yang tidak dimasukan ke dalam model.

Tabel 11.

Hasil Analisis Jalur Persamaan Regresi 2

\begin{tabular}{llccccc}
\hline Model & & \multicolumn{2}{c}{$\begin{array}{c}\text { Unstandardized } \\
\text { Coefficients } \\
\text { B }\end{array}$} & $\begin{array}{c}\text { Standardized } \\
\text { Coefficients } \\
\text { Beta }\end{array}$ & T & Sig. \\
\hline $1 \quad$ (Constant) & 0.009 & 1.437 & & 0.006 & 0,995 \\
& Celebrity Endorser & 0.498 & 0.115 & 0.460 & 4.331 & 0,000 \\
& Brand Awareness & 0.464 & 0.118 & 0.417 & 3.928 & 0,000 \\
R2 $^{2} \quad: 0,641$ & & & & & \\
F statistic $:$ : 50.938 & & & & & \\
Sig. F $\quad: 0,000$ & & & & &
\end{tabular}

Berdasarkan hasil analisis jalur persamaan regresi 2 seperti yang disajikan pada Tabel 11. maka didapat persamaan struktural sebagai berikut:

$$
\mathrm{Y}=0,460 \mathrm{X}+0,417 \mathrm{Y}_{1}
$$

Nilai $\beta_{2}$ sejumlah 0,460 berarti celebrity endorser berpengaruh positif terhadap purchase intention, apabila variabel celebrity endorser meningkat maka meningkatkan variabel purchase intention sepatu Adidas Yeezy di Provinsi Bali sebesar 0,460 .

Nilai $\beta_{3}$ seumlah 0,417 berarti brand awareness berpengaruh positif terhadap purchase intention, hal ini berarti apabila variabel brand awareness meningkat maka variabel purchase intention sepatu Adidas Yeezy di Provinsi Bali akan meningkat sebesar 0,417. Besarnya pengaruh variabel bebas terhadap variabel terikat yang ditunjukkan oleh nilai determinasi total ( $\mathrm{R}$ square) sebesar 0,641 mempunyai arti bahwa sebesar 64,1 persen variasi purchase intention dipengaruhi oleh variasi celebrity endorser dan brand awareness, sedangkan sisanya sebesar 35,9 persen dijelaskan oleh faktor lain ke dalam model. 
Menguji nilai koefisien determinasi $\left(\mathrm{R}^{2}\right)$ dan variabel error (e) berdasarkan model struktur 1 dan struktur 2, maka dapat disusun model diagram jalur akhir. Sebelum menyusun model diagram jalur akhir,terlebih dahulu dihitung nilai standar error sebagai berikut.

$$
\begin{aligned}
& \mathrm{Pe}_{\mathrm{i}}=\sqrt{1-\mathrm{R}} \mathrm{i}^{2} \\
& \mathrm{Pe}_{\mathrm{i}}=\sqrt{1-\mathrm{R}} \mathrm{i}^{2}=\sqrt{1-0,442}=\sqrt{0,558}=0,746 \\
& \mathrm{Pe}_{2}=\sqrt{1-\mathrm{R}} \mathrm{i}^{2}=\sqrt{1-0,641}=\sqrt{0,359}=0,599
\end{aligned}
$$

Berdasarkan hasil perhitungan pengaruh error (Pei), maka hasil pengaruh error $\left(\mathrm{Pe}_{\mathrm{i}}\right)$ yang didapat sebanyak 0,746 dan pengaruh error $\left(\mathrm{Pe}_{2}\right)$ sebanyak 0,599. Setelah menganalisis $\mathrm{e}_{1}$ dan $\mathrm{e}_{2}$, maka didapat perhitungan koefisien determinasi total sebagai berikut:

$$
\begin{aligned}
\mathrm{R}^{2} \mathrm{~m} & =1-\left(\mathrm{Pe}_{1}\right)^{2}\left(\mathrm{Pe}_{2}\right)^{2} \ldots \ldots \ldots \\
& =1-(0,746)^{2}(0,599)^{2} \\
& =1-0,556 \times 0,358 \\
& =1-0,199 \\
& =0,801
\end{aligned}
$$

Nilai determinasi total sebesar 0,801 memiliki arti bahwa 80,1 persen variabel purchase intention dipengaruhi oleh variabel celebrity endorser dan brand awareness, sisanya sebesar 19,9 persen dijelaskan oleh faktor lain di luar model yang dibentuk.

Pengaruh variabel celebrity endorser $(\mathrm{X})$ terhadap brand awareness $\left(\mathrm{Y}_{1}\right)$ :

$$
\mathrm{X} \longrightarrow \mathrm{Y}_{1}=0,665
$$

Pengaruh variabel celebrity endorser $(\mathrm{X})$ terhadap purchase intention $\left(\mathrm{Y}_{2}\right)$ :

$$
\mathrm{X} \longrightarrow \mathrm{Y}_{2}=0,460
$$

Pengaruh variabel brand awareness $\left(\mathrm{Y}_{1}\right)$ terhadap purchase intention $\left(\mathrm{Y}_{2}\right)$ :

$$
\mathrm{Y}_{1} \longrightarrow \mathrm{Y}_{2}=0,417
$$

Pengaruh variabel celebrity endorser $(\mathrm{X})$ terhadap purchase intention $\left(\mathrm{Y}_{1}\right)$ dengan brand awareness $\left(\mathrm{Y}_{2}\right)$ sebagai variabel perantara:

$$
\begin{aligned}
\mathrm{X} \longrightarrow \mathrm{Y}_{1} \longrightarrow \mathrm{Y}_{2} & =(0,665) \times(0,417) \\
& =0,277
\end{aligned}
$$

Untuk memahami pengaruh total (total effect) dapat dilakukan dengan menambah pengaruh langsung celebrity endorser terhadap purchase intention lalu mengalikan pengaruh langsung celebrity endorse terhadap brand awarenes dengan pengaruh langsung brand awarenes terhadap purchase intention.

Total pengaruh variabel $\mathrm{X}$ terhadap $\mathrm{Y}_{2}$ melalui $\mathrm{Y}_{1}$ dapat dirumuskan sebagai berikut:

$$
\begin{aligned}
\text { Total effect } & =0,460+(0,665 \times 0,417) \\
& =0,737
\end{aligned}
$$


Berdasarkan hasil olah data diperoleh nilai probabilitas signifikansi sebesar 0.000 dengan nilai koefisien beta sebesar 0,665, dan nilai t sebesar 6,783 dengan tingkat signifikansi $0.000<0,05$, maka $\mathrm{H}_{0}$ ditolak dan $\mathrm{H}_{1}$ diterima. Hasil ini mempunyai arti bahwa celebrity endorser secara positif dan signifikan berpengaruh terhadap brand awareness. Berdasarkan hasil olah data diperoleh nilai probabilitas signifikansi sebesar 0.000 dengan nilai koefisien beta sebesar 0,460 , dan nilai $\mathrm{t}$ sebesar 4,331 dengan tingkat signifikansi $0.000<0,05$, maka $\mathrm{H}_{0}$ ditolak dan $\mathrm{H}_{2}$ diterima. Hasil ini mempunyai arti bahwa celebrity endorser berpengaruh secara positif dan signifikan terhadap purchase intention. Berdasarkan hasil olah data diperoleh nilai probabilitas signifikansi sebesar 0.000 dengan nilai koefisien beta sebesar 0,417, dan nilai t sebesar 3.928. dengan tingkat signifikansi $0.000<0,05$, maka $\mathrm{H}_{0}$ ditolak dan $\mathrm{H}_{3}$ diterima. Hasil ini mempunyai arti bahwa brand awareness berpengaruh secara positif dan signifikan terhadap purchase intention. berikut:

Perhitungan pengaruh antar variabel dirangkum dalam Tabel 12. sebagai

Tabel 12.

Pengaruh Langsung dan Pengaruh Tidak Langsung serta Pengaruh Total

Celebrity Endorser (X), Brand Awareness ( $\left.\mathrm{Y}_{1}\right)$, dan Purchase Intention ( $\left.\mathrm{Y}_{2}\right)$

\begin{tabular}{cccc}
\hline & $\begin{array}{c}\text { Pengaruh } \\
\text { Langsung }\end{array}$ & $\begin{array}{c}\text { Pengaruh Tidak Langsung Melalui } \\
\text { Brand Awareness } \\
(\mathbf{Y 1})(\boldsymbol{\beta} 1 \mathbf{x} \boldsymbol{\beta} 3)\end{array}$ & $\begin{array}{c}\text { Pengaruh } \\
\text { Total }\end{array}$ \\
\hline $\mathrm{X} \rightarrow \mathrm{Y}_{1}$ & 0,665 & - & 0,665 \\
$\mathrm{X} \rightarrow \mathrm{Y}_{2}$ & 0,460 & 0,277 & 0,737 \\
$\mathrm{Y}_{1} \rightarrow \mathrm{Y}_{2}$ & 0,417 & - & 0,417 \\
\hline
\end{tabular}

Sumber: Data diolah, 2019

Data tersebut menunjukkan bahwa celebrity endorser berpengaruh langsung terhadap purchase intention sebesar 46,0 persen, dengan dimediasi oleh variabel brand awareness maka didapatkan pengaruh tidak langsung sebesar 27,7 persen, dan pengaruh total sebesar 73,7 persen. Hasil tersebut menunjukkan bahwa brand awareness memediasi pengaruh celebrity endorser terhadap purchase intention secara parsial.

Uji sobel merupakan alat analisis untuk menguji signifikansi dari hubungan tidak langsung antara variabel independen dengan variabel dependen yang dimediasi oleh variabel mediator. Uji Sobel dirumuskan dengan persamaan berikut dan dapat dihitung dengan menggunakan aplikasi Microsoft Excel 2010. Bila nilai kalkulasi Z lebih besar dari 1,96 (dengan tingkat kepercayaan 95 persen), maka variabel mediator dinilai secara signifikan memediasi hubungan antara variabel terikat dan variabel bebas.

Uji sobel dihitung dengan rumus dibawah ini:

$$
\begin{aligned}
& \mathrm{Z}=\frac{a b}{\sqrt{\mathrm{a}^{2} \mathrm{~S}_{\mathrm{b}}{ }^{2}+\mathrm{b}^{2} \mathrm{~S}_{\mathrm{a}}{ }^{2}+\mathrm{S}_{\mathrm{a}}^{2} \mathrm{~S}_{\mathrm{b}}^{2}}} \\
& \operatorname{Sig}=(1-\operatorname{NORMDIST}(Z)) 2))
\end{aligned}
$$




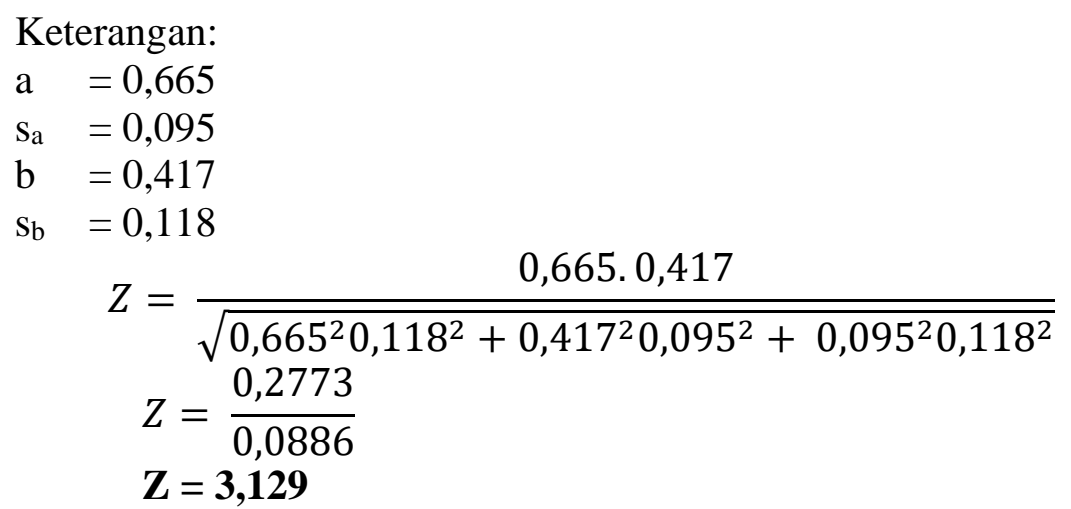

Tabel 13. Hasil Uji Sobel

\begin{tabular}{rc}
\hline Nilai $\mathbf{Z}$ & Sig \\
\hline 3,129 & 0,000 \\
\hline Sumber: Data diolah, 2019 &
\end{tabular}

Berdasarkan hasil uji sobel pada Tabel 13. menunjukan bahwa nilai $\mathrm{Z}$ hitung sebesar 3,129 > 1,96 dengan nilai signifikansi 0,000 $<0,05$, yang artinya brand awareness merupakan variabel yang memediasi pengaruh celebrity endorser terhadap purchase intention pada sepatu Adidas Yeezy di Provinsi Bali atau dengan kata lain celebrity endorser berpengaruh secara tidak langsung terhadap purchase intention melalui brand awareness.

Berdasarkan hasil analisis celebrity endorser terhadap purchase intention diperoleh nilai Signifikansi sebesar 0,000 dengan nilai koefisien beta 0,460 dengan nilai t sebesar 4,331. Nilai Signifikansi $0,000<0,05$ mengindikasikan bahwa $\mathrm{H}_{0}$ ditolak dan $\mathrm{H}_{1}$ diterima. Hasil dalam penelitian ini berarti bahwa celebrity endorser berpengaruh secara positif dan signifikan terhadap purchase intention. Hal ini menunjukkan seorang celebrity endorser yang terkenal, memiliki kemampuan berkomunikasi, dan berpenampilan menarik akan dapat meningkatkan purchase intention pada sepatu Adidas Yeezy.

Hasil penelitian ini sesuai dengan penelitian sebelumnya yang dilakukan oleh Foong \& Yazdanifard (2014), Priyankara et al. (2017), Alatas \& Tarbani (2018), Rajasekar (2018), dan Hani et al. (2018). Hasil penelitian ini juga sesuai dengan penelitian yang dilakukan oleh Putra \& Sulistyawati (2015). Penelitian yang dilakukan oleh Putra \& Sulistyawati (2015) menggunakan indikator penelitian yang sama yaitu visibility, credibility, attraction, dan power dalam meneliti pengaruh celebrity endorser terhadap purchase intention. Hasil penelitian ini juga sama dengan penelitian yang dilakukan oleh (Putera, 2017). Penelitian yang dilakukan oleh Putera (2017) menggunakan objek penelitian yang sama yaitu Adidas Yeezy serta meneliti pengaruh variabel celebrity endorser (Kanye West) terhadap purchase intention. Hasil penelitian yang dilakukan oleh Putera (2017) juga menyatakan bahwa Kanye West sebagai celebrity endorser berpengaruh terhadap meningkatnya purchase intention pada produk Adidas Yeezy.

Roshan \& Sudiksa (2019)mengungkapkan hal yang sama bahwa penggunaan celebrity endorser berpengaruh terhadap meningkatnya purchase intention produk lipstick dari Wardah di Kota Denpasar. Hasil penelitian ini sesuai dengan penelitian 
yang dilakukan oleh (Roshan \& Sudiksa, 2019). Penelitian yang dilakukan oleh Roshan \& Sudiksa (2019) menggunakan teknik analisis yang sama yaitu path analysis serta uji sobel.

Hasil penelitian ini berbeda dengan penelitian yang dilakukan oleh Stephanie et al. (2013) yang menyatakan bahwa penggunaan celebrity endorser tidak berpengaruh terhadap meningkatnya atau menurunya purchase intention pada produk AXE Anarchy di Surabaya. Penelitian yang dilakukan oleh Stephanie et al. (2013) menggunakan pengujian model fit dan penelitian dilakukan di Surabaya.

Berdasarkan hasil analisis celebrity endorser terhadap brand awareness diperoleh nilai Signifikansi sebesar 0,000 dengan nilai koefisien beta 0,665 dengan nilai t sebesar 6,783. Nilai Signifikansi 0,000 $<0,05$ mengindikasikan bahwa $\mathrm{H}_{0}$ ditolak dan $\mathrm{H}_{2}$ diterima. Hasil dalam penelitian ini berarti bahwa celebrity endorser berpengaruh secara positif dan signifikan terhadap brand awareness. Hal ini menunjukkan seorang celebrity endorser yang terkenal, memiliki kemampuan berkomunikasi, dan berpenampilan baik akan dapat meningkatkan brand awareness dari sepatu Adidas Yeezy

Hasil penelitian ini sesuai dengan penelitian sebelumnya yang dilakukan oleh Sintani (2016), Patra (2016), Paramhita \& Purnami (2018), Pramesti et al. (2017), dan Ugwuanyi et al. (2018). Hasil penelitian ini juga sesuai dengan penelitian yang dilakukan oleh Ateke \& Onwujiariri (2016) yang menyatakan bahwa penggunaan celebrity endorser dapat meningkatkan brand awareness pada suatu produk. Penelitian yang dilakukan oleh Ateke \& Onwujiariri (2016) mengungkapkan bahwa penggunaan celebrity endorser dapat meningkatkan brand recall dan brand recognition perusahaan makanan cepat saji di Port Harcourt yang berarti bahwa penggunaan celebrity endorser akan meningkatkan brand awareness.

Feiz et al. (2018) menyatakan hal yang sama bahwa seorang celebrity endorser yang terkenal dan berpenampilan menarik dapat meningkatkan brand awareness pada iklan sepeda motor Honda Beat. Penelitian yang dilakukan Feiz et al. (2018) meneliti pengaruh kelompok musisi JKT 48 sebagai celebrity endorser terhadap brand awareness iklan Honda Beat.

Berdasarkan hasil analisis brand awareness terhadap purchase intention diperoleh nilai Signifikansi sebesar 0,000 dengan nilai koefisien beta 0,417 dengan nilai t sebesar 3,928. Nilai Signifikansi $0,000<0,05$ mengindikasikan bahwa $\mathrm{H}_{0}$ ditolak dan $\mathrm{H}_{3}$ diterima. Hasil dalam penelitian ini berarti bahwa brand awareness berpengaruh secara positif dan signifikan terhadap purchase intention. Hal ini menunjukkan merek Adidas Yeezy yang semakin dikenali, diingat, dan dijadikan pilihan utama oleh masyarakat akan meningkatkan purchase intention pada sepatu Adidas Yeezy.

Hasil penelitian ini sesuai dengan penelitian sebelumnya yang dilakukan oleh Ali \& Syadam (2015), Orlando (2015), Akhmedov (2016), Shahid et al. (2017), Dewi \& Sulistyawati (2018), Omoruyi \& Echinomona (2019). Hasil penelitian ini juga sesuai dengan penelitian yang dilakukan oleh Purnomo (2018) yang menyatakan bahwa meningkatnya brand awareness produk Herbalife di Surabaya berpengaruh terhadap meningkatnya purchase intention masyarakat. Penelitian yang dilakukan Purnomo (2018) menggunakan kuesioner dalam pengumpulan data yang disebarkan pada konsumen Herbalife di Surabaya. Hasil penelitian ini juga 
sesuai dengan penelitian yang dilakukan oleh Eliasari \& Sukaatmadja (2017) yang menyatakan bahwa tingginya brand awareness air minum Kaori berpengaruh terhadap meningkatnya purchase intention masyarakat di Kota Denpasar.

Berdasarkan hasil pengujian hipotesis keempat $\mathrm{H}_{4}$ diperoleh hasil nilai $\mathrm{Z}$ sebesar 3,129 yang lebih besar dari nilai $\mathrm{Z}$ tabel sebesar 1,96, hal ini menunjukkan bahwa $\mathrm{H}_{4}$ dapat diterima, sehingga dapat diartikan bahwa brand awareness mampu memediasi pengaruh celebrity endorser terhadap purchase intention dengan kata lain celebrity endorser berpengaruh secara tidak langsung terhadap purchase intention melalui brand awareness.

Hasil penelitian ini sesuai dengan penelitian yang dilakukan oleh Paramhita \& Purnami (2018) menyatakan bahwa brand awareness mampu memediasi pengaruh celebrity endorser terhadap purchase intention calon pengguna Bukalapak.com. Penelitian yang dilakukan oleh Paramhita \& Purnami (2018) menggunakan teknik analisis yang sama yaitu path analysis serta uji sobel. Hasil penelitian yang sama juga diungkapakan oleh Setiawan (2018) yang menyatakan bahwa brand awareness mampu memediasi pengaruh celebrity endorser terhadap purchase intention pada produk Green Tea Esprecielo. Wijayaningrum et al. (2018) juga menyatakan hal yang sama bahwa brand awareness mampu memediasi pengaruh celebrity endorser terhadap purchase intention Oppo Smartphone di Malang.

Berdasarkan penelitian yang telah dilakukan dapat diketahui bahwa secara teoritis, penelitian ini secara keseluruhan mendukung beberapa teori yang telah ada sebelumnya. Hasil penelitian ini mendukung konsep yang dikemukakan oleh Shimp (2014:260) tentang lima atribut celebrity endorser untuk memfasilitasi efektivitas komunikasi yang disebut dengan akronim TEARS (trustworthiness, expertise, attractiveness, respect, similarity). Hasil penelitian ini juga mendukung konsep yang dikemukakan oleh Aaker (2013:206) yang mengungkapkan bahwa keberhasilan membangun brand awareness sangat ditentukan oleh persepsi konsumen terhadap selebriti yang menjadi ikon produk karena konsumen cenderung mengevaluasi informasi yang diberikan oleh ikon atau selebriti dari produk tersebut.

Hasil penelitian ini juga mendukung konsep dari Durianto et al. (2004:54) yang mengungkapkan bahwa brand awareness atau kesadaran merek menggambarkan kesanggupan seorang calon pembeli untuk mengenali, mengingat kembali suatu merek sebagai bagian dari suatu kategori produk tertentu. Hasil penelitian ini juga mendukung konsep dari Schiffman et al. (2010:23) tentang purchase intention (niat beli) yaitu sesuatu kekuatan psikologis yang ada di dalam seorang individu, yang berdampak pada timbulnya sebuah tindakan. Tindakan ini berupa mencari informasi, melakukan pembelian, dan merekomendasikan suatu produk tertentu. Hasil penelitian ini juga mendukung konsep dari Schiffman et al. (2010:26) yang menyatakan bahwa semakin tinggi niat beli seseorang, maka semakin tinggi juga kesediaan konsumen untuk melakukan tindakan pembelian pada produk tersebut.

Hasil penelitian ini memberikan sebuah implikasi kepada perusahaanperusahaan yang bergerak di bidang fashion atau bidang lainnya mengenai 
bagaimana pentingnya celebrity endorser dan brand awareness dapat memengaruhi purchase intention pada suatu produk.

Implikasi yang pertama, seorang celebrity endorser yang memiliki kemampuan berkomunikasi yang baik dapat membuat konsumen percaya dan memutuskan untuk membeli suatu produk. Celebrity endorser yang terkenal dan memiliki penampilan yang menarik dapat meningkatkan niat beli konsumen terhadap suatu produk.

Implikasi yang kedua, suatu merek yang dikenali dan diingat oleh konsumen dapat menjadi alternatif pilihan bagi konsumen ketika melakukan pembelian pada suatu produk. Penggunaan simbol yang menarik pada suatu merek dapat meningkatkan brand awareness konsumen terhadap merek tertentu.

\section{SIMPULAN}

Hasil penelitian ini menunjukkan bahwa celebrity endorser berpengaruh positif dan signifikan terhadap brand awareness, artinya apabila terjadi perubahan celebrity endorser sepatu Adidas Yeezy maka akan berpengaruh terhadap brand awareness dari sepatu tersebut. Pengaruh hubungan menunjukkan nilai positif ini berarti bahwa semakin baik citra celebrity endorser dari sepatu Adidas Yeezy maka akan meningkatkan brand awareness sepatu Adidas Yeezy. Hasil penelitian ini menunjukkan bahwa celebrity endorser berpengaruh positif dan signifikan terhadap purchase intention, artinya apabila terjadi perubahan celebrity endorser sepatu Adidas Yeezy maka akan berpengaruh terhadap purchase intention dari sepatu tersebut. Pengaruh hubungan menunjukkan nilai positif ini berarti bahwa semakin baik citra celebrity endorser dari sepatu Adidas Yeezy maka akan meningkatkan purchase intention sepatu Adidas Yeezy. Hasil penelitian ini menunjukkan bahwa brand awareness berpengaruh positif dan signifikan terhadap purchase intention, artinya apabila terjadi perubahan brand awareness sepatu Adidas Yeezy maka akan berpengaruh terhadap purchase intention dari sepatu tersebut. Pengaruh hubungan menunjukkan nilai positif ini berarti bahwa semakin baik citra brand awareness dari sepatu Adidas Yeezy maka akan meningkatkan purchase intention sepatu Adidas Yeezy. Brand awareness mampu memediasi pengaruh celebrity endorser terhadap purchase intention. Hal ini menggambarkan bahwa pengaruh variabel celebrity endorser terhadap purchase intention mengalami peningkatan dengan adanya variabel brand awareness.

\section{REFERENSI}

Aaker, D. A. (2013). Manajemen Pemasaran Strategis. Jakarta: Salemba Empat.

Abbas, A., Afsha, G., Aslam, I., \& Ewaz, L. (2018). The Effect of Celebrity Endorsement on Customer Purchase Intention : A Comparative Study. Current Economics and Management Research, 4(1), 1-10.

Akhmedov, R. (2016). Social Networking to Expand Brand Awareness and Influence on Purchase Intention. Journal of Suleyman Demiret University, 8(2). 
Alatas, S. L., \& Tarbani, M. (2018). Pengaruh Celebrity Endorser Terhadap Purchase Intention Melalui Brand Credibility. Jurnal Manajemen Dan Inovasi, 9(1), 91-105.

Ali, A., \& Syadam, S. (2015). An Analysis Study of Improving Brand Awareness and It's Impact on Consumer Behaviour Via Media in North Cyprus (A Case Study of Fast Food Restaurants). International Journal of Business and Social Science, 6(1).

Ateke, B. W., \& Onwujiariri, J. C. (2016). Brand Awareness: Does Celebrity Endorsement Help? University of Port Harcourt Joural of Accounting and Business, 3(1), 246-258.

Chin, V. V., Yun, C. T., \& Fai, P. L. (2017). The Effect of Celebrity Endorsement on Brand Attitude and Purchase Intention. Journal of Global Business and Social Entrepreneurship, 1(4), 141-150.

Danforth, C. (2019). The Top 10 Most Valuable Sneakers of 2019. Retrieved from www.highsnobiety.com website: https://www.highsnobiety.com/p/mostexpensive-sneakers-2019-q3/

Dewi, V. C., \& Sulistyawati, E. (2018). Peran Brand Awareness Memediasi Pengaruh Iklan Terhadap Niat Beli (Studi Pada Produk Pasta Gigi Merek Sensodyne Di Kota Denpasar). E-Jurnal Manajemen Universitas Udayana, 7(4), 1742. https://doi.org/10.24843/ejmunud.2018.v07.i04.p02

Durianto, D., Sugiarto, \& Sitinjak, T. (2004). Strategi Menakhlukan Pasar Melalui Riset Ekuitas dan Perilaku Merek. Jakarta: Gramedia Pustaka Utama.

Eliasari, P. R. A. E., \& Sukaatmadja, I. P. G. (2017). Fakultas Ekonomi dan Bisnis Universitas Udayana, Bali , Indonesia dan mengingat merek dalam situasi yang berbeda. Kesadaran merek terdiri atas. E-Jurnal Manajemen Unud, 6(12), 6620-6650.

Feiz, R. S., Yulianto, E., \& Sunarti. (2018). Pengaruh Celebrity Endorser JKT 48 Terhadap Brand Awareness Pada Iklan Honda Beat (Studi pada Mahasiswa Fakultas Ilmu Administrasi Universitas Brawijaya Malang) Reyhan. Jurnal Administrasi Bisnis (JAB), 65(1), 65-73.

Foong, L. S., \& Yazdanifard, R. (2014). Celebrity Endorsement as a Marketing Tool. Global Journal Of Management And Business Research: E Marketing, 14(4), 37-40. Retrieved from http://journalofbusiness.org/index.php/GJMBR/article/viewFile/1429/1336

Hani, S., Marwan, A., \& Andre, A. (2018). The Effect of Celebrity Endorsement on Consumer Behavior: Case of The Lebanese Jewelry Industry. Arab Economic and Business Journal, 13, 190-196.

Hastuti, R. K. (2019). Diburu Sejak Pagi, Sepatu Adidas Seharga Rp 3,6 Juta Ludes. Retrieved from CNBC Indonesia website: https://www.cnbcindonesia.com/lifestyle/20190607160546-33-77069/diburu- 
sejak-pagi-sepatu-adidas-seharga-rp-36-juta-ludes

Kahle, L. R., \& Homer, P. M. (2016). Physical Attractiveness of the Celebrity Endorser: A Social Adaptation Perspective. Journal of Consumer Research, 11(4), 954-961. https://doi.org/10.1086/209029

Keller, K. L. (2003). Strategic Brand Management: Building, Measuring, and Managing Brand Equity. New Jersey: Prentice Hall.

Kotler, P., \& Armstrong, G. (2008). Prinsip-prinsip Pemasaran (12th ed.). Jakarta: Erlangga.

Kotler, P., \& Keller, L. K. (2008). Manajemen Pemasaran. Jakarta: Erlangga.

Lova, C. (2019). Demi Adidas Yeezy 350 V2, Warga Rela Antre Panjang Pukul 06.00 di GI. Retrieved from Kompas.com website: https://megapolitan.kompas.com/read/2019/06/07/10380931/demi-adidasyeezy-350-v2-warga-rela-antre-panjang-pukul-0600-di-gi\#source=clicktitle

Omoruyi, \& Echinomona. (2019). Evaluating The Effects of Brand Advertising, Brand Element and Brand Awareness on Purchasing Intention. Journal of Contemporary Management, 3(1), 422-449.

Orlando, D. (2015). Analisa Pengaruh Brand Image dan Brand Awareness Terhadap Purchase Intention Sepeda Motor " Kawasaki Ninja 250Fi “ Program Manajemen Pemasaran Universitas Kristen Petra. Jurnal Managemen Pemasaran Petra, Vol.3(Issue.1), Hal.2. Retrieved from https://media.neliti.com/media/publications/134813-ID-analisa-pengaruhbrand-image-dan-brand-a.pdf

Paramhita, A. . S. K., \& Purnami, N. M. (2018). Peran Brand Awareness Memediasi Hubungan Kredibilitas Endorser Dengan Online Purchase Intention Melalui Situs Belanja Online. Prosiding Seminar Nasional Manajemen Dan Bisnis III (SNMB3), 324-338.

Patra, S. (2016). Role of Bollywood Celebrities in Generating Brand Awareness and Preference in Kolkata. Journal of Avensha, 7(4).

Pramesti, N. N. T. M., Pascaran, N. N. D., \& Joni, I. D. A. S. (2017). Pengaruh Penggunaan Selebriti Endorser Terhadap Brand Awareness Akun Instagram @ georgiosstore Di Kalangan Siswi SMA Negeri 1 Denpasar. Fakultas Ilmu Sosial Dan Ilmu Politik Universitas Udayana Email:, 1(1).

Priyankara, R., Weerasiri, S., Dissanayaka, R., \& Jinadasa, M. (2017). Celebrity Endorsement and Consumer Buying Intention With Relation to The Television Advertisement for Perfumes. University of Kelaniya Journal of Management Studies, 5(2), 128-148.

Purnomo, T. (2018). Pengaruh Kesadaran Merek Dan Citra Merek Terhadap Niat Beli Pada Konsumen Herbalife Di Surabaya. Agora, 6(1), 1-7.

Putera, D. D. (2017). Pengaruh Celebrity Endorser Kanye West Terhadap Minat 
Ida Bagus Putu Asdhi Setiawan, Peran Brand Awareness...

Beli Pada Produk Adidas Yeezy. E-Proceeding of Management Journal, 4(1), 792-800.

Putra, I. K. T. D., \& Sulistyawati, E. (2015). Peran Brand Image dalam Memediasi Pengaruh Celebrity Endorser terhadap Niat Beli. E-Jurnal Manajemen Unud, 4(6), 1722-1734.

Rajasekar, D. (2018). A study on purchase decisions of celebrity endorsement on advertising campaign in influencing consumer: Impact analysis. International Journal of Supply Chain Management, 7(1), 230-235.

Riduwan, \& Kuncoro, A. (2011). Cara Menggunakan dan Memaknai Analisis Jalur (Path Analysis) (3rd ed.). Bandung: Alfabeta.

Roshan, P. A. A., \& Sudiksa, I. B. (2019). Peran Brand Image Memediasi Pengaruh Celebrity Endorser Terhadap Purchase Intention. E-Jurnal Manajemen Universitas Udayana, 8(8), 5164. https://doi.org/10.24843/ejmunud.2019.v08.i08.p17

Safiera, A. (2016). Adidas Yeezy Kanye West, Sepatu dengan Nilai Jual Tertinggi di 2016. Retrieved from wolipop.detik.com website: https://wolipop.detik.com/fashion-news/d-3257827/adidas-yeezy-kanyewest-sepatu-dengan-nilai-jual-tertinggi-di-2016

Schiffman, L. G., Kanuk, L. L., \& Wisenblit, J. (2010). Consumer Behavior (10th ed.). Prentice Hall: Upper Saddle River, N.J.

Setiawan, L. (2018). Pengaruh Celebrity Endorsement Terhadap Purchase Intention Dengan Brand Awareness Sebagai Variabel Mediasi pada Produk Green Tea Esprecielo Allure. Jurnal Manajemen Pemasaran, 12(1), 53-59. https://doi.org/10.9744/pemasaran.12.1.53

Shahid, Z., Hussain, T., \& Azafar, F. (2017). The Impact of Brand Awareness on The Consumers Purchase Intention. Journal of Marketing and Consumer Research, 33(2).

Shimp, A. T. (2014). Komunikasi Pemasaran Terpadu dalam Periklanan dan Promosi (8th ed.). Jakarta: Salemba Empat.

Sintani, L. (2016). Pengaruh Penggunaan Celebrity Endorser Isyana Sarasvati Dalam Iklan "Isyana vs Gangster" Terhadap Brand Awareness Masyarakat Surabaya. Jurnal E-Komunikasi, 4(1). Retrieved from https://media.neliti.com/media/publications/82789-ID-pengaruhpenggunaan-celebrity-endorser-i.pdf

Stephanie, E., Rumambi, L. J., \& Sondang, Y. (2013). Analisa Pengaruh Rio Dewanto dan Donita Sebagai Celebrity Endorser Terhadap Minat Beli Produk Axe Anarchy Dengan Daya Tarik Iklan dan Efek Iklan Sebagai Variabel Intervening. Jurnal Manajemen Pemasaran, 1(2), 1-9.

Ugwuanyi, Christian, C., Vivian, C., \& Nnabugwu, L. (2018). Celebrity 
Advertising, Brand Awareness and Brand Recognition : A Structural Equation Modelling Approach. Europan Journal of Business and Management, 10(28), $17-24$.

Wijayaningrum, L. A., Kusumawati, A., \& Nuralam, I. P. (2018). The effect of celebrity endorser on brand awareness and it's impact on purchase decision. (Study on Undergraduate Student User of Oppo Smartphone in Malang City). Administrasi Bisnis, 60(3), 78-86.

www.topbrand-award.com. (2019). Top Brand Index Sepatu Olahraga Tahun 2019. Retrieved from www.topbrand-award.com website: https://www.topbrandaward.com/top-brand-index/?tbi_year=2019 